\title{
KARATERISTIK FISIKA KIMIA DAN BIOLOGI PERAIRAN DANAU TEMPE DI SEKITAR SOPPENG SEBAGAI DASAR TEKNIK PENGELOLAAN SUMBER DAYA PERIKANAN TANGKAP
}

\author{
Supriyono Eko Wardoyo"), Irin Iriana") dan Bambang Priono")
}

\begin{abstract}
ABSTRAK
Danau Tempe merupakan danau terbesar di Propinsi Sulawesi Selatan. Wilayah perairan danau ini meliputi Kabupaten Wajo, Sidrap dan Soppeng. Sebenarnya Danau Tempe merupakan kesatuan dari tiga danau, yaitu Danau Tempe itu sendiri, danau Sidenreng dan danau Buaya. Pada waktu saat musim hujan, luapan banjir dari beberapa sungai yang bermuara ke danau mengakibatkan ke tiga danau tersebut menjadi satu genangan (luas genangannya dapat mencapai 35.000 ha pada elevasi $7.8 \mathrm{dpl}$ ). Pada kondisi air naik biasanya pada musim hujan aktivitas usaha perikanan sangat dominan, tetapi di saat kondisi air turun yang biasanya pada musim kemarau usaha tanaman pangan sangat dominan. Walaupun luasan danau cukup besar, produksi ikan dari tahun $1950 \mathrm{~s} / \mathrm{d} 1992$ terus mengalami penurunan meskipun telah ada usaha restocking ikan di danau.
\end{abstract}

Tujuan dilakukannya penelitian ini adalah untuk mengetahui karakteristik fisika, kimia dan biologi perairan Danau Tempe di daerah Soppeng, termasuk komposisi populasi ikan yang ada di Kecamatan Marioriawa. Hal ini penting sebagai dasar dalam pengelolaan perikanan Danau Tempe. Penelitian dilakukan melalui wawancara dengan nelayan setempat, observasi pengukuran kualitas air dilakukan di lapangan dan di laboratorium, serta sampling populasi ikan.

Hasil penelitian yang diperoleh menunjukkan bahwa secara fisik lingkungan Danau Tempe di sekitar Soppeng banyak tertutupi tumbuhan air terutama Eceng gondok (Eichornia crassipes) dan kangkung (Ipomoea aquatica). Sedangkan kualitas air menunjukkan bahwa kandungan DO dan nitrit sudah melewati ambang batas baku mutu. Hal tersebut disebabkan adanya pembusukan tanaman air yang banyak tumbuh di badan air danau. Kandungan pestisida dalam air seperti Endosulfan, Lindane dan Heptachlor telah terdeteksi, namun masih di bawah batas ambang kecuali jenis Heptachlor. Sementara itu, hasil analisis biologi perairan Danau Tempe menunjukkan bahwa plankton berjumlah kecil (152 ind/l) dan yang tumbuh dominan adalah jenis Anabaena sp. yang ternyata sangat baik sebagai pakan alami ikan. Hasil perhitungan keseimbangan komposisi ikan di Danau Tempe wilayah Soppeng menyimpulkan adanya dominasi ikan-ikan predator dan binatang air lainnya yang bersifat predator, yaitu ular air, sedangkan jenis ikan prey yang berukuran besar jumlahnya terbatas (sedikit). Beberapa rekomendasi teknologi pengelolaan perikanan Danau Tempe telah disampaikan dalam laporan ini.

ABSTRACT: Physical, chemical and biological characteristics of Lake Tempe arround Soppeng area, as basic data for its fisheries management, By: Supriyono Eko Wardoyo, Irin Iriana and Bambang Priono

Lake Tempe is a biggest lake in South Sulawesi province. Area of the lake covers Regencies of Wajo, Sidrap and Soppeng. Lake Tempe complex consists of 3 small lakes: Lake Tempe, Lake Sidenreng, and Lake Buaya. In rainy season, flood of rivers enters to the lake and makes the three small lakes unite and reach an area of 35,000 ha at elevation of $7.8 \mathrm{~m}$ from sea level. During high water surface usually in rainy season, fisheries activities become dominant, in contrary during low water surface usually in dry season, food crops cultivation takes over. Fish production of the lake was decreasing, although fish restocking has been done. 
The objective of the study is to see physical, chemical and biological characteristics of the lake in Soppeng area, including the fish population composition in Marioriawa district. This is important as a basic data for fisheries management of the lake. Method used in the study was interviews with fishermen, observation, water quality determination and fish population sampling.

The results showed that most lake was covered widely by aquatic weed especially water hyacinth (Eichornia crassipes) and kangkung (Ipomoea aquatica). It was recommended to control this weed in order to increase plankton primary productivity. Water quality showed that DO and nitrite content was over the threshold limit, which presumably due to decomposition of aquatic weed. Pesticide contents in the water such as Endosulfan, Lindane and Heptachlor were detected, however, they were still under threshold limit except for the Heptachlor. The number of plankton was very low (152 ind/l) and Anabaena sp. was the dominant species in the lake. This species is one of natural food of fish. Computation of fish population balance showed that the fish predator and predatory aquatic animal (aquatic snake) population were too many compared to prey fish population. Some recommendations of the lake management techniques were presented in the report.

KEYWORDS: Fisheries management, water quality, pesticide, prey fish

\section{PENDAHULUAN}

Danau Tempe merupakan danau terbesar di Propinsi Sulawesi Selatan, wilayah perairan danau ini meliputi Kabupaten Wajo, Sidrap dan Soppeng. Luas genangan Danau Tempe adalah 13.000 ha, Danau Sidenreng 3.000 ha, dan Danau Buaya 300 ha. Pada waktu musim hujan, luapan banjir dapat mengakibatkan ketiga danau tersebut menjadi satu genangan dengan luas mencapai 35.000 ha pada elevasi 7,8 dpl (Anonimous, 1993). Luas daerah pasang-surutnya di sekeliling danau dapat mencapai lebih dari 18.000 ha, yang sebagian besar dapat dimanfaatkan untuk areal tanaman palawija. Selain daerah pasang-surut yang luas, ciri danau ini adalah landai, dangkal dan banyak ditumbuhi oleh tumbuhan air, sehingga perairan Danau Tempe ini merupakan perairan yang bercirikan rawa banjiran.

Tinggi muka air Danau Tempe sangat dipengaruhi oleh beberapa sungai dan musim di masing-masing sektor. Musim di sektor barat berpengaruh melalui. Sungai WalanaE, Lawo, Batu-batu dan Bilokka, sedangkan musim di sektor timur berpengaruh melalui Sungai Bila. Sungai CenranaE adalah satusatunya out-let Danau Tempe. Musim hujan baik di sektor barat pada bulan Desember-Januari, maupun di sektor timur pada bulan Maret-April mengakibatkan genangan air Danau Tempe meningkat (Whitten et al., 1987). Pada kondisi air pasang aktivitas usaha perikanan sangat dominan, tetapi di saat kondisi air surut usaha tanaman pangan sangat dominan.

Produksi ikan Danau Tempe menunjukkan penurunan dari 48.000 ton pada tahun 1950 menjadi 16.000 ton pada tahun 1992 (Cholik and Anggraeni, 1994), walaupun pemerintah setempat telah melakukan restocking sebesar 10 ton pada awal tahun 1992 (Hasanudin et al, 1993).

Tujuan penelitian ini adalah untuk mengetahui karakteristik fisika, kimia dan biologi perairan Danau Tempe di daerah Soppeng, utamanya komposisi 
populasi ikan yang ada di Kecamatan Marioriawa. Dengan data yang didapatkan diharapkan dapat memberikan masukan positif yang menyangkut teknik pengelolaan perikanan Danau Tempe bagi pemerintahan daerah Tk. I Sulawesi Selatan utamanya di Kabupaten Soppeng.

\section{BAHAN DAN METODE PENELITIAN}

Penelitian dilakukan melalui wawancara dengan nelayan setempat, observasi dan pengukuran kualitas air dilakukan di lapangan pada jam $10.00 \mathrm{~s} / \mathrm{d} 11.00$ pagi $(\mathrm{pH}$, suhu dan $\mathrm{DO})$ dan di laboratorium $\left(\mathrm{NO}_{2}, \mathrm{NO}_{3}, \mathrm{BOT}, \mathrm{PO}_{4}\right.$ dan $\mathrm{NH}_{4}$ ). Analisa kandungan pestisida di Balitvet Bogor menggunakan kromatografi gas, dengan pengambilan sampel pada musim hujan dan musim kemarau. Analisa plankton dilakukan di mana sample diambil dengan menggunakan plankton net ukuran mesh No 25 yang selanjutnya dianalisis di laboratorium Puslitbang Perikanan.

Untuk melihat komposisi ikan dilakukan sampling dengan cara memplot 2 hamparan perairan di daerah yang bebas dan yang penuh tanaman air dengan luas masing-masing $100 \mathrm{~m}^{2}$ serta kedalaman 1-1,25 m yang dibatasi dengan jaring berukuran mata $1,8 \mathrm{~cm}$, dan tinggi 1,50 meter serta dilengkapi dengan pelampung dan pemberat. Ikan-ikan pada hamparan tersebut diracun dengan saponin, yaitu suatu bahan yang terbuat dari biji teh yang dapat terurai dengan cepat namun tidak mengganggu lingkungan danau. Setelah kurang lebih satu hari ikan-ikan yang mati teracun dan terjerat di jaring dikumpulkan dan kemudian satu persatu ditentukan jenis, berat dan panjangnya.

Swingle (1950) mengusulkan 6 parameter dinamika populasi dengan kisaran angka keseimbangan populasi ikan sebagai berikut:

$\mathrm{F} / \mathrm{C}=$ Perbandingan berat total ikan prey terhadap ikan predator dengan angka keseímbangan antara 1,4-10.

$\mathrm{Y} / \mathrm{C}=$ Perbandingan berat total ikan prey kecil terhadap ikan predator besar. Dengan angka keseimbangan antara 0,02-4,8.

$\mathrm{A}_{\mathrm{T}} \quad=$ Persentase berat total ikan ukuran besar (prey dan predator) terhadap total sample. Dengan angka keseimbangan 33-40.

$\mathrm{A}_{\mathrm{F}} \quad=$ Persentase berat ikan prey ukuran besar terhadap total ikan prey. dengan angka keseimbangan 18,2-99,6.

$\mathrm{I}_{\mathrm{F}} \quad=$ Persentase berat ikan prey ukuran-ukuran sedang terhadap total ikan prey. Dengan angka keseimbangan 0-41,4.

$\mathrm{S}_{\mathrm{F}} \quad=$ Persentase berat ikan prey ukuran kecil terhadap total ikan prey. Dengan angka keseimbangan 0,4-80,9.

Suatu populasi ikan boleh dikatakan seimbang apabila keenam parameter tersebut di atas masih di dalam kisaran angka keseimbangan. Apabila ada satu 
atau lebih parameter di luar angka keseimbangan maka populasi ikan tersebut dinyatakan tidak seimbang. Batasan ikan kecil adalah < $50 \mathrm{~g}$, sedang 50-100 g, dan besar $>100 \mathrm{~g}$.

Lokasi penelitian keseluruhannya dilakukan di perairan Danau Tempe, yaitu di sekitar wilayah perairan Soppeng, di Kecamatan Marioriawa.

\section{HASIL DAN PEMBAHASAN}

\section{Keadaan Umum Perikanan}

Kabupaten Soppeng merupakan salah satu Kabupaten yang mengelilingi D. Tempe di Sulawesi Selatan. Luas areal Danau Tempe yang masuk Kabupaten Soppeng kurang lebih 3000 ha. Daerah yang dikuasai perorangan (palawang) seluas 1800 ha, sedangkan daerah bebas kurang lebih 1200 ha. Hasil produksi perikanan di daerah Soppeng dijual rata-rata $1 / 3$ bagian ke pasar di daerah Soppeng dan 2/3 bagian ke luar daerah Soppeng. Akan tetapi seluruh pasar di Soppeng memasukkan ikan 15 ton/hari berupa ikan laut dari Sinjai dan Barru (kontak pribadi dengan Kepala Dinas Perikanan Soppeng).

Keadaan lingkungan Danau Tempe di daerah Soppeng sekitar 80\% sudah tertutupi tumbuhan air terutama Eceng gondok (Eichornia crassipes) dan kangkung (Ipomoea aquatica). Tumbuh-tumbuhan air tersebut cocok untuk tempat bersembunyi dan berkembang biak ular yang merupakan pemangsa ikan-ikan kecil. Di samping itu penutupan permukaan air oleh tumbuhtumbuhan dapat menghambat tumbuhnya produksi primer plankton.

\section{Sifat Fisik dan Kimia Air}

Pada penelitian ini sampling kualitas air dilakukan di lokasi yang dapat mewakili areal lainnya. Hasil pengukuran/analisis sifat fisika kimia air Danau Tempe di daerah Soppeng dapat dilihat pada Tabel 1.

Tabel 1. Kualitas air Danau Tempe di daerah Soppeng Table 1. Water quality of Lake Tempe in Soppeng area

\begin{tabular}{|c|c|c|c|c|}
\hline \multicolumn{2}{|c|}{ Parameter } & \multicolumn{2}{|c|}{ Nilar/Value } & \multirow{2}{*}{$\begin{array}{l}\text { Angka standart } \\
\text { Standard value }\end{array}$} \\
\hline & & \multicolumn{2}{|c|}{ Permukaan / Upper Dasar / Bottom } & \\
\hline $\mathrm{pH}$ & & 7,0 & 7,0 & $6-9$ \\
\hline Suhu( & .) $\mathrm{C}$ & 28 & 29 & $28-32$ \\
\hline DO & ppm & 8 & 4 & $6-8$ \\
\hline $\mathrm{NO}_{2}$ & ppm & 0,341 & 0,341 & 0,06 \\
\hline BOT & ppm & 5,09 & 4,97 & $0,1-50,0$ \\
\hline $\mathrm{PO}_{4}$ & ppm & 0,1337 & 0,1138 & $0,06-10,00$ \\
\hline $\mathrm{NH}_{4}$ & ppm & 0,0575 & 0,0546 & $<1$ \\
\hline
\end{tabular}

* (Menteri KLH, 1988; Boyd, 1984) 
Dari Tabel 1 dapat dilihat bahwa kualitas air secara keseluruhan layak untuk kehidupan ikan, hanya nitrit terlalu tinggi, yaitu 0,3413 , angka ini di atas ambang batas yaitu $0,06 \mathrm{ppm}$. Ini diduga disebabkan karena banyaknya tumbuhan air sehingga terjadi pembusukan yang menyebabkan nitrit tinggi nilainya. Hal ini dapat membahayakan kehidupan ikan jika tidak diantipasi, karena nitrit merupakan racun bagi ikan. Demikian juga kandungan DO di dasar yang terlalu rendah, diakibatkan juga oleh pembusukan tumbuhtumbuhan air.

Hasil pemeriksaan kandungan pestisida dalam air Danau Tempe menunjukkan bahwa pada musim hujan kandungan Endosulfan dalam perairan Danau Tempe mencapai $0,0171 \mathrm{ppm}$, sedangkan pada musim kemarau mencapai 0,0212 ppm. Deteksi kandungan pestisida Lindane pada musim hujan mencapai 0,0002 ppm, sedangkan pada musim kemarau kandungan pestisida Heptachlor mencapai $0,0058 \mathrm{ppm}$. Kandungan pestisida dalam air Danau Tempe diduga muncul sebagai akibat banyaknya penggunaan pestisida oleh petani palawija yang aktivitasnya dilakukan pada saat air danau surut. Oleh karena itu, pengambilan sampel air guna pengukuran kandungan pestisida yang terkandung di dalamnya dilakukan pada saat air tertinggi (Januari) dan terendah (Agustus). Nampaknya, kandungan pestisida air Danau Tempe masih di bawah ambang batas yang ditentukan. Nilai ambang batas maksimum kandungan pestisida air untuk jenis Endosulfan 0,04 ppm, Lindane 0,1 ppm dan Heptachlor 0,003 ppm (Anonimous, 1985). Nampak bahwa kandungan pestisida Heptachlor hasil pengukuran sampel lebih tinggi daripada nilai ambang yang ditentukan. Namun demikian secara umum kadar residu pestisida yang terkandung dalan air Danau Tempe masih di bawah ambang batas (belum membahayakan kehidupan biota yang ada).

\section{Aspek Biologi Perairan}

Fitoplankton, zooplankton dan perifiton merupakan makanan hidup bagi larva dan benih ikan dan berperan sebagai sumber karbohidrat, lemak, protein dengan susunan asam amino yang lengkap serta mineral. Kehidupan nabati/hewan air tersebut ada kaitannya dengan produktivitas ikan. Hasil analisa jenis-jenis plankton di Danau Tempe lokasi Soppeng bulan Agustus 1993 menunjukkan jumlah yang kecil (152 ind/l) seperti dalam Tabel 2. Hal ini diduga merupakan akibat tertutupnya permukaan air oleh tumbuh-tumbuhan air sehingga produksi primer kurang karena kurang sinar matahari. Sebagai perbandingan kandungan plankton di Rawa Taliwang mencapai $2000 \mathrm{ind} / \mathrm{l}$, Waduk Saguling (Jawa Barat) 4000-170.000 ind/1 dan Danau Sentani sekitar 1800 ind/1 (Sarnita dan Jangkaru, 1977). Perlu dilaporkan pula bahwa wilayah perairan Soppeng di Danau Tempe sekitar $80 \%$ ditutupi oleh tumbuhtumbuhan air, terutama jenis eceng gondok dan kangkung. 
Tabel 2. Komposisi jenis-jenis fitoplankton di Danau Tempe daerah Soppeng Table 2. Composition of phytoplankton at Lake Tempe in Soppeng area

\begin{tabular}{l|c}
\hline \hline \multicolumn{1}{c|}{$\begin{array}{c}\text { Jenis plankton } \\
\text { Type of plankton }\end{array}$} & $\begin{array}{c}\text { Jumlah individu/1 } \\
\text { Total individu/ }\end{array}$ \\
\hline Chlorophyta & 3 \\
Cyanophyta & \\
- Dactyloccocopsis & 3 \\
- Anabaena & 119 \\
Diatome & 18 \\
- Nitzcbia & 9 \\
- Diatome & 152 \\
\hline Jumlah (Total) & \\
\hline \hline
\end{tabular}

\section{Keseimbangan Komposisi antara Ikan-ikan Prey dan Predator}

Kriteria-kriteria keseimbangan populasi ikan (prey-predator) didasarkan pada Swingle (1950) yang telah melakukan sampling keseimbangan populasi ikan di 88 lokasi perairan yang terdiri dari minimal 2 jenis ikan.

Sampling komposisi ikan telah dilakukan pada 2 lokasi di perairan Soppeng Danau Tempe. Lokasi pertama mewakili daerah yang terbuka, tidak ditutupi oleh tumbuh-tumbuhan air dan lokasi kedua penuh ditumbuhi dengan tumbuhan air. Hasil yang diperoleh dapat dilihat pada Tabel 3 dan 4.

Tabel 3. Hasil sampling komposisi ikan pada daerah yang bebas tumbuhan air Table 3. Fish composition of sampling in the area free of aquatic weed

\begin{tabular}{|c|c|c|c|c|c|}
\hline \multicolumn{3}{|c|}{$\begin{array}{l}\text { Ikan pemangsa dan binatang } \\
\text { pemangsa lain / Predator }\end{array}$} & \multicolumn{3}{|c|}{ Ikan pakan (Prey) / non Predator } \\
\hline $\begin{array}{l}\text { Nama / } \\
\text { Name }\end{array}$ & $\begin{array}{l}\text { Jumlah } \\
\text { Count }\end{array}$ & $\begin{array}{l}\text { Berat } \\
\text { Weigbt (g) }\end{array}$ & $\begin{array}{l}\text { Nama / } \\
\text { Name }\end{array}$ & $\begin{array}{l}\text { Jumlah } \\
\text { Count }\end{array}$ & Berat \\
\hline $\begin{array}{l}\text { Kecil } \\
\text { - Bungo }\end{array}$ & 3 & 48 & $\begin{array}{l}\text { - Sepat } \\
\text { - Betok }\end{array}$ & $\begin{array}{l}24 \\
22\end{array}$ & $\begin{array}{l}120 \\
130\end{array}$ \\
\hline Sub Total & & 48 & & & 250 \\
\hline $\begin{array}{l}\text { Sedang } \\
\text { - Ular air }\end{array}$ & 12 & 1080 & - & - & \\
\hline $\begin{array}{l}\text { Besar } \\
\text { - Ular air }\end{array}$ & 2 & 250 & - & - & \\
\hline Total & & 1378 & & & 250 \\
\hline
\end{tabular}


Tabel 4. Hasil sampling komposisi ikan pada areal yang ditumbuhi tanaman air

Table 4. Fish compositon of sampling in the area covered with aquatic weed

\begin{tabular}{|c|c|c|c|c|c|}
\hline \multicolumn{3}{|c|}{$\begin{array}{l}\text { Ilkan permangsa dan binatang } \\
\text { pemangsa lain / Predator }\end{array}$} & \multicolumn{3}{|c|}{ Ikan pakan (Prey) / non Predator } \\
\hline $\begin{array}{l}\text { Nama I } \\
\text { Name }\end{array}$ & $\begin{array}{l}\text { Jumlah } \\
\text { Count }\end{array}$ & $\begin{array}{c}\text { Berat } \\
\text { Weight (g) }\end{array}$ & $\begin{array}{l}\text { Nama ' } \\
\text { Name }\end{array}$ & $\begin{array}{l}\text { Jumlah } \\
\text { Count }\end{array}$ & $\begin{array}{l}\text { Berat } \\
\text { Weight (g) }\end{array}$ \\
\hline \multicolumn{6}{|l|}{ Kecil } \\
\hline - Gabus & 3 & 40 & - Sepat & 12 & 70 \\
\hline - Bungo & 1 & 10 & - Betok & 25 & 160 \\
\hline Sub Total & & 50 & & & 230 \\
\hline Sedang & & & - & - & \\
\hline - Ular & 6 & 480 & & & \\
\hline Besar & & & - & - & \\
\hline - Ular & 3 & 375 & & & \\
\hline Total & & 905 & & & 230 \\
\hline
\end{tabular}

$$
\begin{aligned}
& \mathrm{F} / \mathrm{C}=250 / 1378 \quad=0,18 \quad \ldots-\cdots>\text { tidak seimbang } \\
& \mathrm{Y} / \mathrm{C}=250 / 250 \quad=1 \quad \ldots \\
& A_{T}=250 / 1628 \times 100 \%=15,35 \text {-.---> tidak seimbang } \\
& A_{F}=0 / 250 \times 100 \% \quad=0 \quad-\cdots \text { tidak seimbang } \\
& I_{F} \quad=0 / 250 \times 100 \% \quad=0 \quad-\cdots>\text { seimbang } \\
& \mathrm{S}_{\mathrm{F}} \quad=250 / 250 \times 100 \%=100 \quad \ldots-\cdots \text { tidak seimbang }
\end{aligned}
$$

Hasil tersebut di atas menunjukkan bahwa terdapat parameter-parameter yang tidak seimbang, yaitu:

$\mathrm{F} / \mathrm{C}=$ Perbandingan berat total ikan prey terhadap ikan predator terlalu kecil.

$A_{F} \quad=$ Persentase berat total ikan ukuran besar terhadap total ikan prey terlalu kecil (0)

$\mathrm{S}_{\mathrm{F}} \quad=$ Persentase berat ikan prey ukuran kecil terhadap total ikan prey terlalu besar. 
Kesimpulan hasil sampling pada areal yang bebas tumbuhan air adalah bahwa: ikan prey kurang dibanding ikan predator terutama ikan prey ukuran besar, karena terlalu banyak ikan predator sehingga ikan prey tidak mempunyai kesempatan untuk hidup menjadi besar, dan umumnya banyak yang kecil-kecil, selain itu diduga karena faktor genetis ikan-ikan prey (betok dan sepat) tidak dapat tumbuh besar. Oleh karena itu, perlu disarankan adanya penebaran ikan-ikan prey yang sifat genetisnya masih baik, seperti ikan mas dan nila.

$$
\begin{aligned}
& \mathrm{F} / \mathrm{C}=230 / 903 \quad=0,25 \quad \cdots-->>\text { tidak seimbang } \\
& \mathrm{Y} / \mathrm{C}=230 / 370 \quad=0,613 \ldots \text { seimbang } \\
& A_{\mathrm{T}}=375 / 1135 \times 100 \%=33,03 \ldots>\text { seimbang } \\
& A_{F}=0 / 230 \times 100 \% \quad=0 \quad-\cdots>\text { tidak seimbang } \\
& I_{F} \quad=0 / 230 \times 100 \% \quad=0 \quad-\cdots>\text { seimbang } \\
& \mathrm{S}_{\mathrm{F}}=230 / 230 \times 100 \%=100 \quad \ldots-\cdots>\text { tidak seimbang }
\end{aligned}
$$

Pada hasil sampling ke dua, menunjukkan bahwa parameter-parameter yang tidak seimbang adalah sebagai berikut:

$\mathrm{F} / \mathrm{C}=$ Perbandingan berat total ikan prey terhadap ikan predator terlalu kecil

$\mathrm{A}_{\mathrm{F}} \quad=$ Persentase berat total ikan ukuran besar terhadap total ikan prey terlalu kecil (0)

$\mathrm{S}_{\mathrm{F}} \quad=$ Persentase berat ikan prey ukuran kecil terhadap total ikan prey terlalu besar.

Dengan demikian dari hasil sampling pada areal yang ditumbuhi tanaman air dapat disimpulkan bahwa: ikan prey kurang dibandingkan ikan predator terurama ikan prey ukuran besar. Ikan sepat dan betok adalah ikan-ikan prey yang secara genetis tidak dapat mencapai ukuran besar. Oleh karena itu perlu disarankan adanya penebaran ikan-ikan prey jenis lainnya yang sifat genetisnya masih baik, seperti ikan mas dan nila.

Dari kedua lokasi sampling, komposisi jenis ikan ternyata mempunyai kesimpulan yang sama, namun pada lokasi yang banyak ditumbuhi tanaman air didapatkan ikan gabus. Ikan gabus adalah salah satu ikan predator yang rupanya senang bersembunyi di sekitar tanaman air.

\section{KESIMPULAN DAN SARAN}

Dari hasil pembahasan maka dapat disimpulkan secara keseluruhan sebagai berikut: 
a. Jenis-jenis pestisida (Endosulfan, Lindane, dan Heptachlor) terdeteksi dalam sampel air Danau Tempe, pada musim kering dan hujan. Namun demikian kandungannya masih dalam batas aman, kecuali Heptachlor.

b. Hasil analisis kualitas air bagi perikanan menunjukkan bahwa, kandungan nitrit di atas ambang batas yang dianjurkan, demikian juga kandungan DO rendah hal ini dapat disebabkan oleh pembusukan tanaman air. Hasil analisis plankton menunjukkan jumlah yang sedikit (152 ind/l), jenis yang dominan adalah Anabaena yang baik sebagai pakan ikan.

c. Berdasarkan observasi di lokasi, ternyata lingkungan Danau Tempe di sekitar Soppeng $( \pm 80 \%)$ tertutupi tumbuhan air terutama eceng gondok (Eichornia crassipes) dan kangkung (Ipomoea aquatica).

d. Hasil perhitungan keseimbangan komposisi ikan di Danau Tempe wilayah Soppeng menyimpulkan adanya dominasi ikan-ikan predator dan binatang pemangsa yang hidup di air lainnya (ular air), ikan-ikan prey ukuran besar kurang.

e. Tumbuhan air perlu dikurangi karena dapat menurunkan produksi primer yang dibutuhkan ikan, dapat menyebabkan terjadinya pembusukan misalnya kadar nitrit menjadi tinggi. Selain itu tumbuhan air dapat dijadikan tempat untuk berlindungnya ular air yang merupakan pemangsa ikan. Pengurangan tumbuhan air sebaiknya tidak dilakukan dengan menggunakan obat-obatan (herbisida) karena dikhawatirkan akan merusak lingkungan danau, dengan demikian pemberantasan secara biologis atau mekanik akan lebih baik.

f. Disarankan untuk mengupayakan peningkatan penebaran jenis-jenis ikan prey yang memiliki sifat genetis baik, seperti ikan mas dan nila.

\section{DAFTAR PUSTAKA}

Anonimous, 1993. Rencana induk pengendalian banjir Danau Tempe dan sekitarnya. Disajikan pada Pertemuan Pembahasan Program Pengelolaan terpadu Danau Tempe di Singkang, 2-3 Agustus 1993. Dinas Pekerjaan Umum Pengairan, Propinsi Dati I Sulawesi Selatan

Anonimous, 1985. Standard for maximum residu limits of pesticides, agricultural chemicals, feed additives, veterinary medicines and noxious substances in food. Commenwealth Departement of Health. Australian Government Publishing Service. Canberra. 53p.

Boyd C.E., 1984. Water Quality Warm Water Fish Pond. Auburn Univ. Agricultural Experiment Station R Dennis Rouse Director/Auburn, Alabama USA, 359 P. 
Cholik F. and M.S.Anggraeni, 1994. Research and needs for integrated management of Lake Tempe. AARD/FAO International Workshop in Sustainable Development of Lake Tempe Basin, Ujung Pandang, Indonesia 4-7 Juli 1994, 18 p.

Hasanuddin A., M.S.Pandang dan S.Bachrein, 1993. Pengembangan usahatani dan pengelolaan secara terpadu kawasan Danau Tempe, Sulawesi Selatan. Makalah disampaikan pada Seminar Hasil Penelitian dan Pengembangan Program Pengelolaan Terpadu Danau Tempe, di Wajo, Propinsi Sulawesi Selatan, 2-3 Agustus 1993. Balai Penelitian Tanaman Pangan Maros, Badan Penelitian dan Pengembangan Pertanian.

Ilyas S., A. Hardjamulia, E.S.Kartamihardja, K.Purnomo. D.W.H.Tjahjo dan D.Sadili, 1991. Petunjuk Teknis Pengelolaan Perairaan Waduk Bagi Pengembangan Perikanan. Seri Pengembangan Hasil Penelitian Perikanan No.PHP/Kan/PT.07a/1989.Badan Penelitian dan Pengembangan Pertanian, Jakarta.

Menteri KLH, 1988. SK Menteri KLH No. 2 th 1988, Tentang Baku Mutu Lingkungan Hidup. Kantor Meneg Lingkungan Hidup.

Swingle H.S., 1950. Relation ships and dynamic of balanced and unbalanced fish populations. Bulletin No. 274. Aquacultural experiment station of the Alabama Polytehnic Institute. 74p.

Sarnita A. dan Z.Jangkaru, 1977. Penelitian perikanan rawa Taliwang dalam rangka usaha peningkatan daya gunanya. Laporan No. 15 LPPD Bogor. 27p.

Whitten A.J., M.Mustafa and G.S.Henderson, 1987. The ecology of Sulawesi. Gajah Mada University Press. Yogyakarta. 